\title{
Crustal structure of central Lake Baikal: Insights into intracontinental rifting
}

\author{
Uri S. ten Brink and Michael H. Taylor ${ }^{1}$ \\ U.S. Geological Survey, Woods Hole, Massachusetts, USA
}

Received 26 January 2001; revised 15 October 2001; accepted 25 October 2001; published 16 July 2002.

[1] The Cenozoic rift system of Baikal, located in the interior of the largest continental mass on Earth, is thought to represent a potential analog of the early stage of breakup of supercontinents. We present a detailed $P$ wave velocity structure of the crust and sediments beneath the Central Basin, the deepest basin in the Baikal rift system. The structure is characterized by a Moho depth of $39-42.5 \mathrm{~km}$; an $8-\mathrm{km}$-thick, laterally continuous high-velocity $(7.05-7.4 \mathrm{~km} / \mathrm{s})$ lower crust, normal upper mantle velocity $(8 \mathrm{~km} / \mathrm{s})$, a sedimentary section reaching maximum depths of $9 \mathrm{~km}$, and a gradual increase of sediment velocity with depth. We interpret the high-velocity lower crust to be part of the Siberian Platform that was not thinned or altered significantly during rifting. In comparison to published results from the Siberian Platform, Moho under the basin is elevated by $<3 \mathrm{~km}$. On the basis of these results we propose that the basin was formed by upper crustal extension, possibly reactivating structures in an ancient fold-and-thrust belt. The extent and location of upper mantle extension are not revealed by our data, and it may be offset from the rift. We believe that the Baikal rift structure is similar in many respects to the Mesozoic Atlantic rift system, the precursor to the formation of the North Atlantic Ocean. We also propose that the Central Baikal rift evolved by episodic fault propagation and basin enlargement, rather than by two-stage rift evolution as is commonly assumed. INDEX TERMS: 8109 Tectonophysics: Continental tectonics-extensional (0905); 8107 Tectonophysics: Continental neotectonics; 8120 Tectonophysics: Dynamics of lithosphere and mantlegeneral; 9320 Information Related to Geographic Region: Asia; KEYWORDS: Lake Baikal, continental rifts, Newark basin, crustal extension, plate driving forces, seismic velocity structure

\section{Introduction}

[2] Most aspects of the deformation of intracontinental rifts can be explained by a combination of several physical parameters [e.g., Ruppel, 1995]: (1) the rheology of the continental lithosphere, in particular, the crust, (2) preexisting heterogeneities within the lithosphere, (3) the thermal structure of the lithosphere, and (4) the rate of extension. Together these parameters determine rift geometry (localized versus distributed crustal extension, reversal in rift polarity, etc.), subsidence pattern, rift-shoulder uplift, the amount and composition of rift-related magmatism, the magnitude of crustal thinning, and rift evolution. The interaction among these parameters is responsible for a variety of rifting mechanisms such as pure shear (lithospheric necking), simple shear, lower crustal flow, and combinations of the above [e.g., Ruppel, 1995].

[3] The Baikal rift system is the largest active Eurasian rift system (Figure 1). It is therefore thought to represent a potential analog for the breakup of supercontinents and to

\footnotetext{
${ }^{1}$ Now at the Department of Earth and Space Sciences, University of California, Los Angeles, California, USA.
}

This paper is not subject to U.S. Copyright.

Published in 2002 by the American Geophysical Union. provide a natural laboratory in which the early stages of continental rifting can be observed. The Baikal rift system has, for many years, been the focus of a debate about the driving forces of continental rifting. Driving forces for intracontinental rifting fall into three categories: (1) far-field stresses within the continental lithosphere due to either plate boundary forces or sublithospheric drag; (2) active buoyancy forces due to dynamic mantle upwelling; and (3) other gravitational effects, such as gravitational collapse and lithospheric delamination [e.g., Ruppel, 1995, and references within]. Far-field stresses that could drive the Baikal rift system are believed to be generated by the Indo-Asian collision [Tapponnier and Molnar, 1979] and possibly by subduction of the Pacific plate along its western boundary [e.g., Calais et al., 1998] and by the configuration of the Siberian Platform as a rigid promontory (Figure 2) [Petit et al., 1997]. An alternative driving force for this rift system is an active asthenospheric upwelling in the vicinity of the rift system [e.g., Zorin and Lepina, 1985], farther to the SE [Windley and Allen, 1993], or on a larger scale under Tibet, Mongolia, and parts of China [Yin, 2000]. A variety of evidence about volcanism, deformation geometry, and thermal structure as well as comparisons with other rift systems, such as the East African rift system and the Rio Grande Rift [Lipman et al., 1989; Lysak, 1987], have been used to support the different points of view. However, these lines 


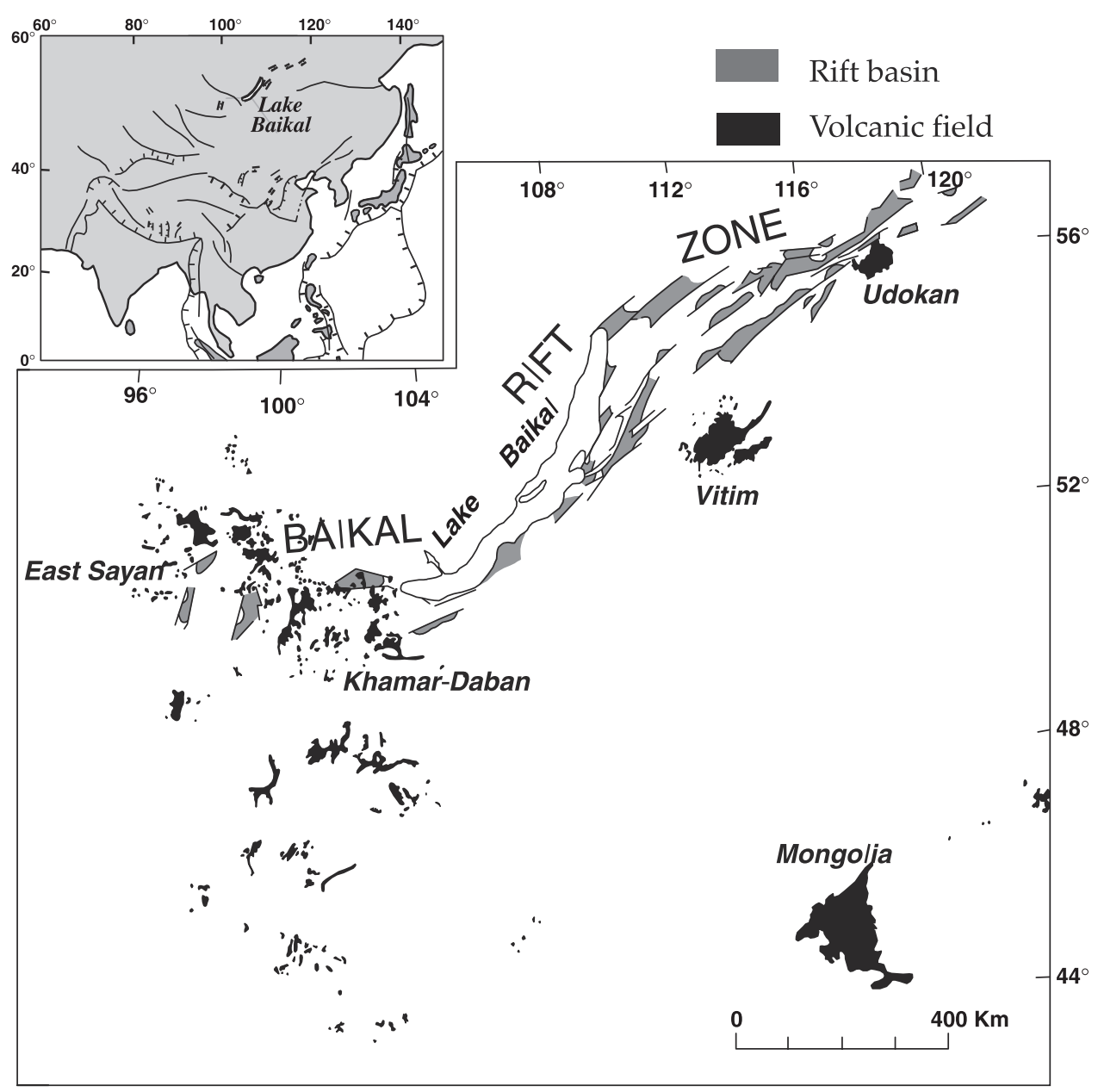

Figure 1. Locations of the 15 basins, which comprise the Baikal rift system and the location of Cenozoic volcanic fields [Kiselev, 1987]. Inset is a generalized tectonic map of East Asia.

of evidence are generally indicative of the particular combination of the above physical parameters, not the driving forces. For example, lithospheric extension due to far-field stresses can lead to passive asthenospheric upwelling, which produces many of the same features as those generated by active asthenospheric upwelling [Holbrook and Kelemen, 1993; Mutter et al., 1988]. We therefore discuss the implications of our results for the rifting mechanisms, not for the driving forces.

[4] We present a detailed $P$ wave velocity structure of the sediments and crust beneath the Central Basin of Lake Baikal (Figures 2 and 3) derived from a joint wide-angle and multichannel seismic reflection (MCS) experiment, conducted in 1992 by the U.S. Geological Survey and the Russian Academy of Sciences. The data offer insight to the rift geometry at depth and the possible mode of extension. The velocity model helps to differentiate between some proposed mechanisms for crustal extension of Lake Baikal [Burov et al., 1994; Lesne et al., 2000; Petit et al., 1997; Poort et al., 1998; van der Beek, 1997]. We use the results to draw an analogy between the geometry of the Baikal rift system and the early Mesozoic Atlantic rift system, the precursor to the formation of the North Atlantic Ocean, where the role of an active asthenopheric upwelling is still debated [e.g., Holbrook and Kelemen, 1993]. We also discuss evidence against the commonly cited two-stage rifting history of the Baikal rift.

\section{Tectonic Setting}

[5] The $\sim 1800-\mathrm{km}$ rift system is composed of 15 individual basins within the Sayan-Baikal fold-and-thrust belt along its boundary with the Siberian Platform (Figures 1 and 2) [Keller et al., 1995, and references therein]. The rift system is dominated by extensional tectonics with a strikeslip component, potentially a result of the southeastward movement of the Amur plate relative to the stable Siberian Platform [e.g., Lesne et al., 1998]. GPS measurements show crustal extension across Lake Baikal at a rate of $4.5 \pm$ $1.2 \mathrm{~mm} / \mathrm{yr}$ in a WNW-ESE direction [Calais et al., 1998] and an extension at a rate of $6.3 \pm 1.8 \mathrm{~mm} / \mathrm{yr}$ in a $125^{\circ} \pm 15^{\circ}$ direction between Irkutsk and Ulan Bataar in Mongolia [Calais and Amarjargal, 2000]. Active extension is also evidenced by frequent magnitude 5 and larger earthquakes [Zonenshain and Savostin, 1981; Doser, 1991; Deverchere et al., 1993]. The Baikal rift system is located within a mountainous region (Figure 2), which is sometimes referred to as a domal uplift [Kiselev, 1987; Logatchev and Zorin, 


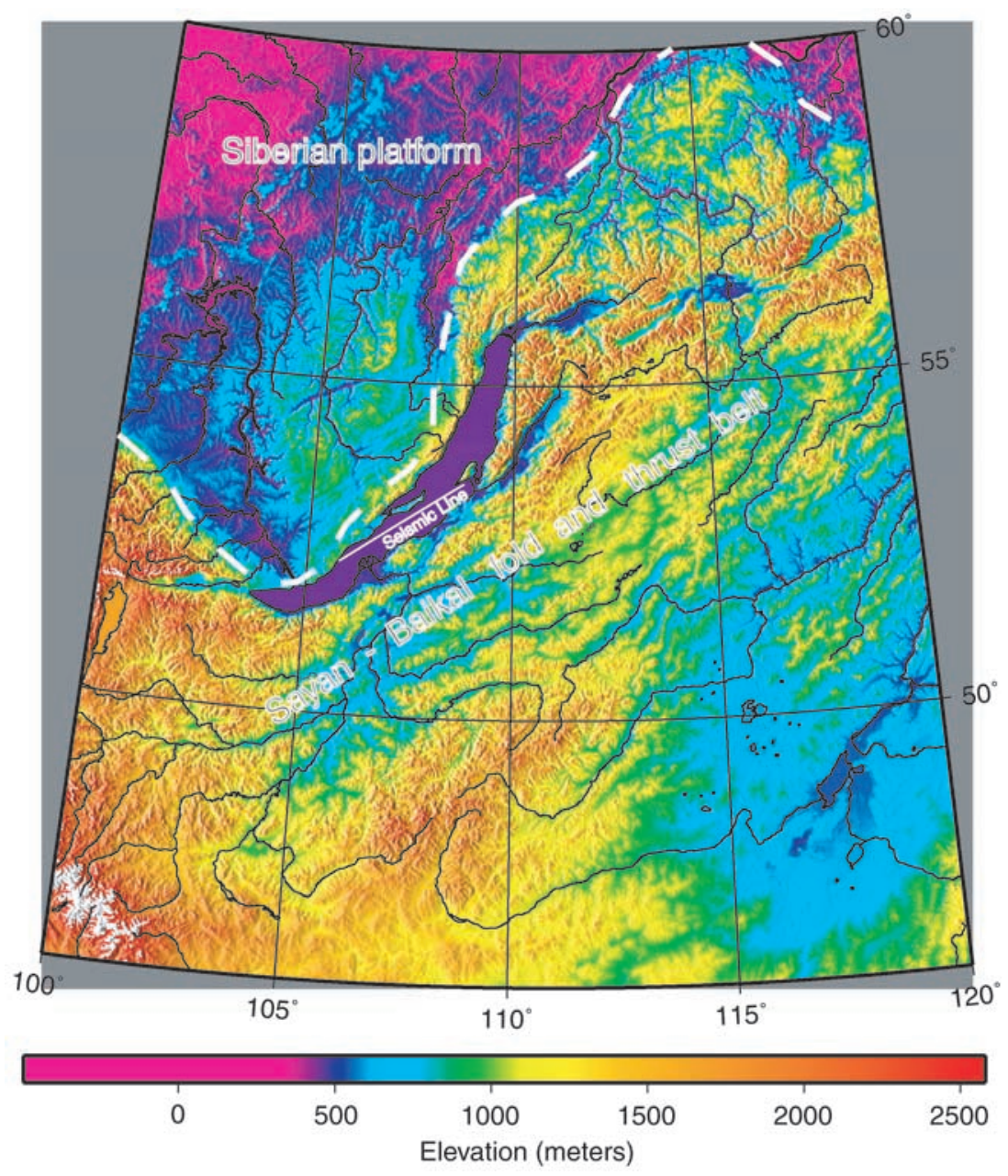

Figure 2. Topography of the Baikal rift and the surrounding areas. Basins form depressions and Lake Baikal. Lake level is at $455 \mathrm{~m}$ above sea level (asl). White dashed line separates the Siberian Platform from the Proterozoic-Paleozoic fold and thrust belt of Trans-Baikal Mongolia. White line shows location of our seismic refraction profile. The high elevation around and southeast of the Baikal rift zone is interpreted by some to represent uplift due to mantle upwelling [e.g., Windley and Allen, 1993].

1987]. The prerift structural framework of the Baikal rift zone is characterized by northeast-southwest trending Precambrian to lower Paleozoic fold-and-thrust belts, widely believed to be a controlling factor in rift evolution [Keller et al., 1995; Mats, 1993; Zamarayev and Ruzhich, 1978].

[6] The rift basins of Lake Baikal occupy the central 650 $\mathrm{km}$ of the rift system and include three major sedimentary basins, the Southern Basin, the Central Basin and the Northern Basin and a deep smaller depocenter, the Selenga Basin (inset in Figure 3) [Hutchinson et al., 1992]. The floor of the Central Basin has the lowest elevation of the entire rift system, $\sim 1650 \mathrm{~m}$ below lake level and $\sim 1190$ m below mean sea level. The deformation in this section of the rift is predominantly confined to the width of the lake, $\sim 60 \mathrm{~km}$. The Morskiy Fault along the northwest edge of the basin appears to be the major boundary of the basin (Figure 3). Bathymetry and overall sediment thickness increase toward this fault [Hutchinson et al., 1992; Moore et al., 1997; Scholz et al., 1993], giving the basin an appearance of a half graben dominated by dip-slip displacements. However, the detailed basin evolution appears to be more complex and may involve periods of transtensional motion, as indicated by periods of relatively symmetric sediment accumulation [Hutchinson et al., 1992; Moore et al., 1997]. In addition, a new boundary fault, the Primorskiy Fault (Figure 3) appears to be progressively replacing the Morskiy Fault as the main boundary fault of the rift [Agar and Klitgord, 1995].

\section{Seismic Data and Model}

[7] A 247-km wide-angle seismic refraction line was recorded by five ocean bottom seismometers (OBS) along the axis of the central basin, with two 60-L air guns as the source (Figure 3). The northern $140 \mathrm{~km}$ of the line were repeated with six OBS and a tuned 10-gun array with a total volume of $27.3 \mathrm{~L}$. Multichannel seismic reflection (MCS) data were recorded simultaneously by a 96-channel, 2400$\mathrm{m}$-long streamer along this portion of the line [Scholz et al., 1993]. For the southern $100 \mathrm{~km}$, MCS line 11 was collected at distances between 4 and $13 \mathrm{~km}$ southeast of the wideangle transect (Figure 3). Continuous high-amplitude wideangle reflections and refractions from the sedimentary 


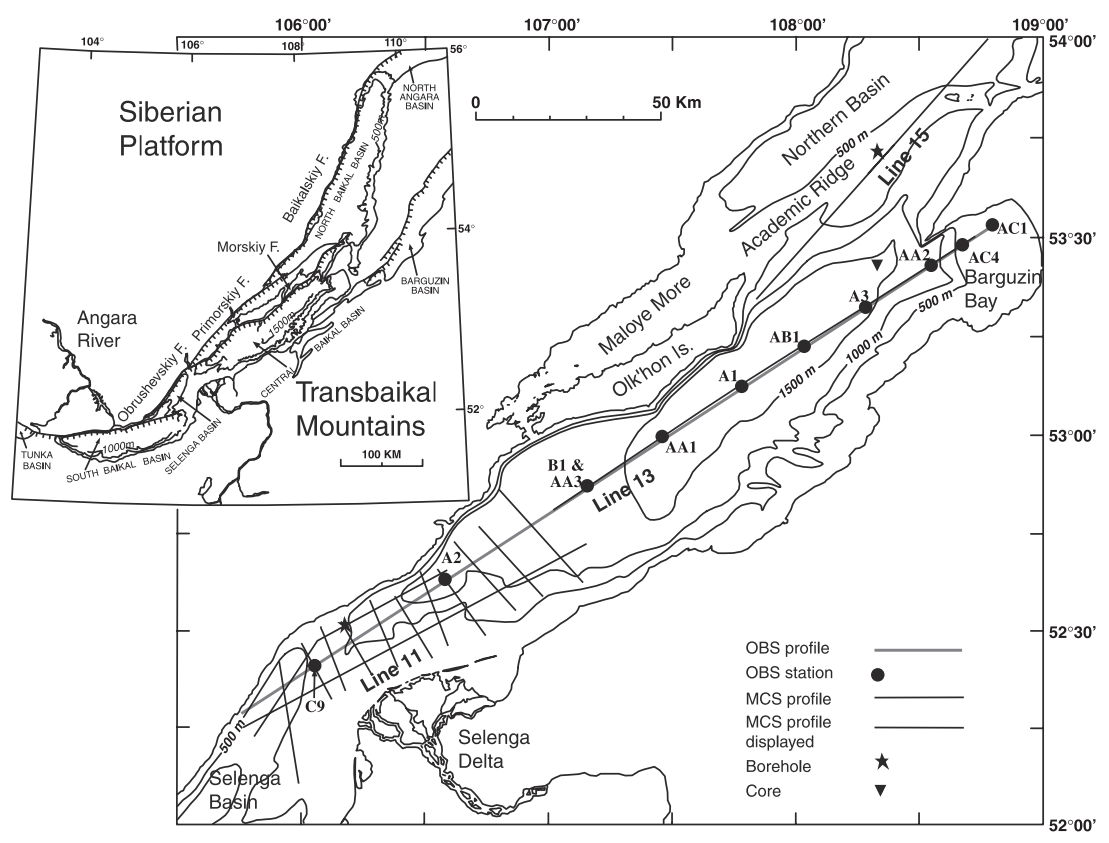

Figure 3. Location of seismic refraction line (gray line) and multichannel seismic reflection lines shown (heavy black lines) or used for interpretation (thin black lines). Ocean bottom seismometer (OBS) names are denoted by letters. Inset shows basins and boundary faults in the vicinity of the Central Basin (modified from Agar and Klitgord [1995]).

section and the top of basement were observed in each OBS record to shot-receiver offsets of $40 \mathrm{~km}$. Discontinuous arrivals are observed to maximum offsets of $170 \mathrm{~km}$ and represent reflections and refractions from the crystalline basement and, in four OBS, from the Moho (Figure 4).

[8] Processing of the wide-angle data included a linear move out correction, spiking deconvolution, low-pass filter of $14 \mathrm{~Hz}$, and automatic gain control (AGC). Processing of the MCS data included prestack spiking deconvolution, iterative velocity analysis, and AGC. Poststack processing included predictive deconvolution, AGC, vertical sum, time-variant filtering, and a cascaded migration scheme [Agena et al., 1994]. Forward travel time modeling of the wide-angle data was carried out utilizing the interactive RayGUI code [Loss et al., 1998], based on Zelt and Smith's [1992] ray-tracing package. Further improvement to the solution was achieved by linearized inversion with the same package (Figure 5). We constructed the starting model by digitizing the seismic structure of basin fill deposits and sparse basement reflections derived from coincident vertical incidence data acquired during the 1992 cruise. Because the southern $100-\mathrm{km}$ portion of the refraction transect lacks a coincident MCS profile, we used information from MCS cross lines there (Figure 3). Tomographic inversion was not attempted because of the small number of data and the poor signal-to-noise ratio. Instead, we obtained an estimate of model resolution by perturbing various parts of the model and observing the decay in model fit (Figure 6) [e.g., Holbrook et al., 1996]. The velocity model consists of nine layers (excluding the water layer), with five layers of sedimentary section and four layers composing the crust and upper mantle (Figure 7a). Ray coverage for the model is generally very good in the sedimentary section and uppermost crust, with resolution decreasing with depth to Moho.
An average root-mean-square (RMS) misfit for the entire model is $0.127 \mathrm{~s}$, and the RMS misfit for the sedimentary section and basement is $0.1 \mathrm{~s}$.

\section{Results}

\subsection{Sedimentary Section}

[9] Our velocity model indicates a maximum thickness of $\sim 9 \mathrm{~km}$ for the sedimentary section, northeast of the Selenga Delta (km 75, Figure 7b), where reflection data did not image basement beneath the deep part of the Central Basin (Figure 8). Depth to basement reaches 8-9 km under other parts of the Central Basin (120-170 along the model). Depth to basement under the Selenga Basin at the southernmost part of the profile reaches $7 \mathrm{~km}$, a value similar to the depth of 6-7.5 km estimated from MCS data [Hutchinson et al., 1992]. The transition to basement is taken as the $5.2 \mathrm{~km} / \mathrm{s}$ isovelocity contour, which corresponds to a clear basement reflection on the MCS data between $\mathrm{km} 170$ and 230 (Figure 8). Velocity of basin fill deposits within the Central Basin increases gradually with increasing depth from the lake floor without abrupt changes in velocity gradient (Figure 7), probably due to sediment compaction. A few wide-angle reflections can be identified in the refraction data in the upper part of the sedimentary section (Figures 4 and 5), but they do not form a coherent reflecting horizon across the model. The gradual increase in velocity and the lack of a reflecting horizon do not support a division of the sedimentary section in the Central Basin into two units of different physical properties, as previously suggested based on their reflectivity in the MCS data [Hutchinson et al., 1992; Scholz et al., 1993]. Amplitude analysis of these data has indeed shown that the loss of reflectivity at 4-4.5 s two-way travel time cuts across seismic horizons 

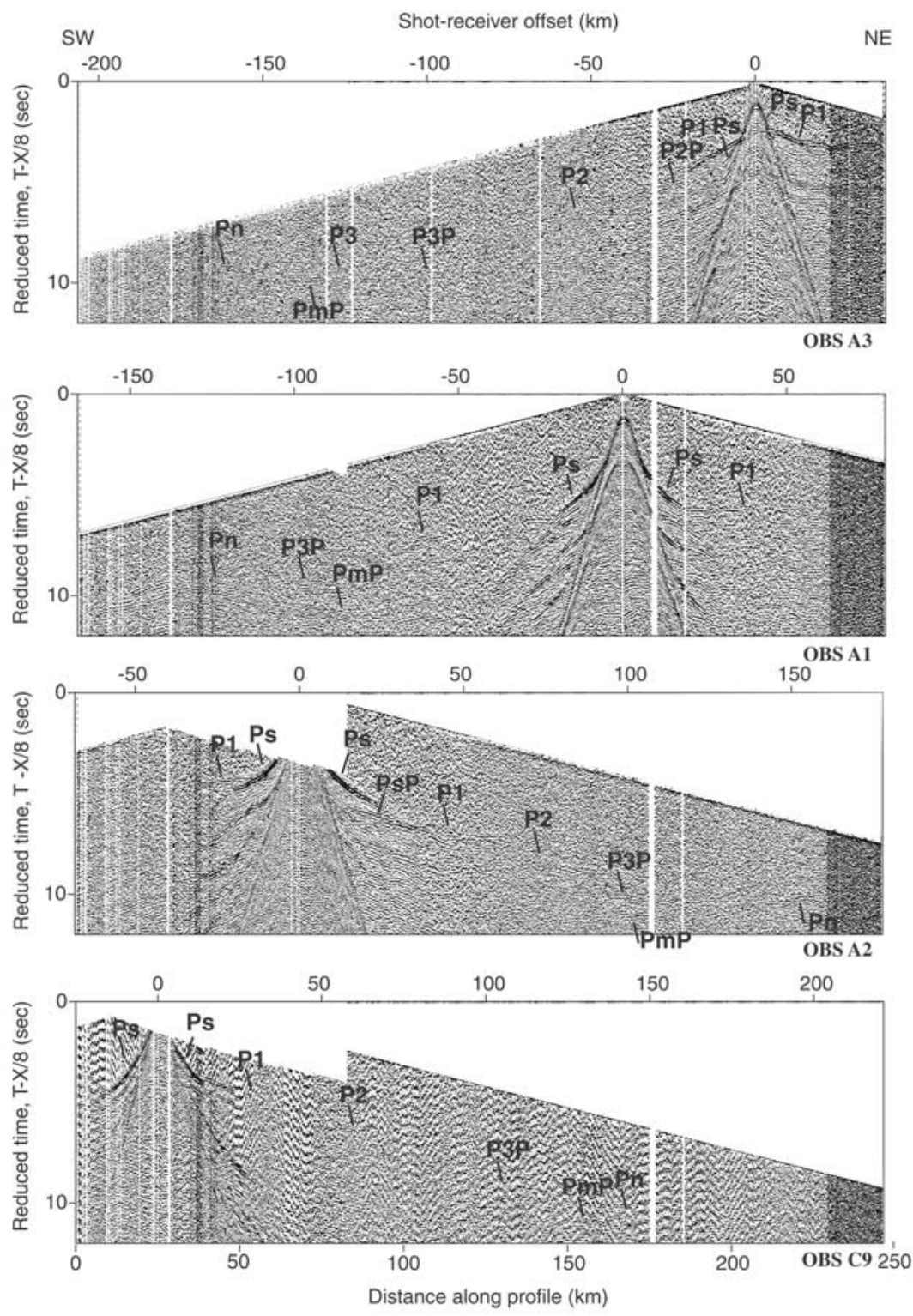

Figure 4. Examples of wide-angle refraction records. Note that discontinuous events can be detected to a maximum offset of $170 \mathrm{~km} . P S, P 1, P 2, P 3$ are turning waves from the sedimentary section, upper crust, middle crust, and the basal high-velocity layer, respectively. $P s P, P 2 P, P 3 P$, and $P m P$ are wide-angle reflections from basement, the middle crust, the top of the basal high-velocity layer, and Moho, respectively. $P n$ is upper mantle head wave.

and is perhaps caused by silica diagenesis [Lee et al., 1996]. Furthermore, the loss of reflectivity was shown to be gradual and to start above the suggested upper/lower unit boundary [Lee et al., 1996].

[10] The basement under the Selenga Delta is shallower than under the adjacent Central and Selenga Basins (Figure 8b). An MCS grid of profiles in the Selenga Delta indicates that the basement high comprises a series of fault blocks with large (3-4 s) vertical throws between them [Scholz et al., 1993; Scholz and Hutchinson, 2000]. Since the Selenga River is the largest sediment source of Lake Baikal, draining much of Mongolia, sedimentation has nearly kept pace with the tectonic movement, resulting in a shallower bathymetry than elsewhere in the lake. Excess sediments are funneled northward to the southern part of the Central Basin and southward to the Selenga Basin [Scholz et al., 1993; S. M. Colman et al., Quaternary depositional patterns and environments in Lake Baikal from high-resolution seismic stratigraphy and coring, unpublished manuscript, 2001].

[11] Near the north end of the Central Basin an abrupt decrease in basement depth by $2-3 \mathrm{~km}$ can be seen in the velocity model northeast of $\sim 170-180 \mathrm{~km}$ (Figure 7 ). The overlying sedimentary section on the MCS profile in this region thins to the northeast and is cut by faults (Figure 8). However, modeling the exact location and shape of the basement rise was difficult because of a lack of travel time 

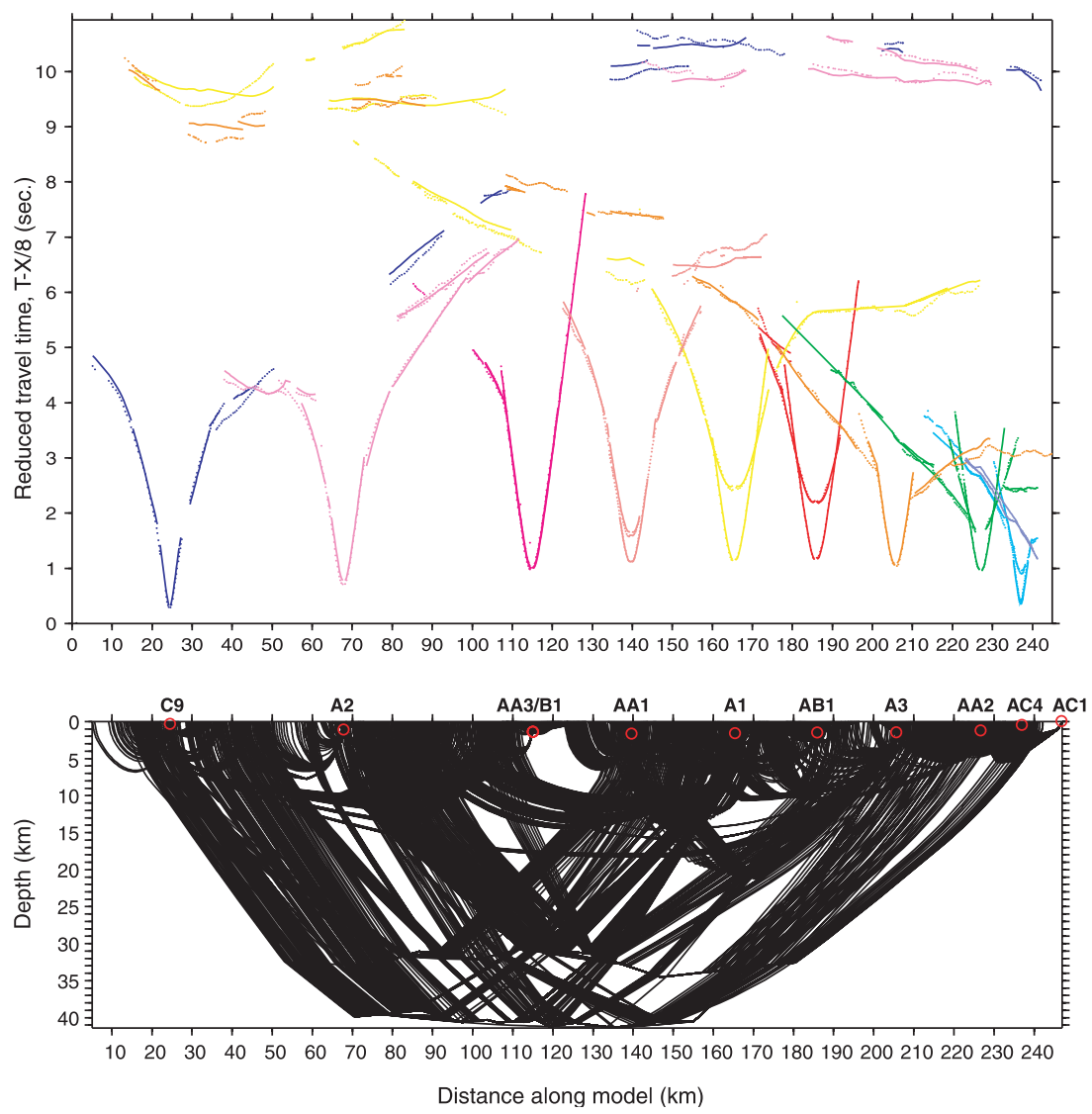

Figure 5. (a) Observed (dots) and calculated (lines) travel time for all OBS. (b) Ray paths for calculated travel times. Travel time modeling was carried out by two-point ray tracing using Zelt and Smith's [1992] linearized inversion program. RMS misfit between the calculated and observed travel times was $0.127 \mathrm{~s}$. A much better fit was obtained for the sedimentary section, $0.1 \mathrm{~s}$, because of better ray coverage.

reciprocity between adjacent OBSs at this location. We explain the lack of reciprocity by out-of-plane effects, perhaps because the profile there lies close to the Morskiy Fault (Figure 3). The Morskiy Fault is a normal fault dipping to the southeast, and at depth it likely underlies our refraction profile. Our velocity model and the grid of MCS profiles in the area [Moore et al., 1997] show that basement continues to shallow over a short distance at 190 $200 \mathrm{~km}$ and is $\sim 1.5 \mathrm{~km}$ below lake bottom in the northernmost $40 \mathrm{~km}$ of the line (Figures $7 \mathrm{~b}$ and 8 ).

[12] The distribution of high-velocity $(3.0-5.2 \mathrm{~km} / \mathrm{s})$ sediments is highly variable (Figure $7 \mathrm{~b}$ ). High-velocity sediments are $\sim 4 \mathrm{~km}$ thick between 80 and $180 \mathrm{~km}$. They are thinner below the Selenga Delta and are missing along the northern part of the Central Basin and Barguzin Bay. This distribution suggests either original deposition in basins of limited size or exhumation and subsequent erosion of uplifted blocks. Seismic stratigraphic analysis suggests that the Central Basin was initially smaller and lengthened with time [Moore et al., 1997]. For example, the sedimentary thickness below Horizon B4 in the Northern Basin, the Academic Ridge, and the northern part of the Central Basin is small $(<500 \mathrm{~m})$ compared with the deep part of the Central Basin (compare Figures 8 and 9). Sediments on the Academic Ridge appear to have filled local depressions and are not heavily eroded [Moore et al., 1997]. In contrast to the high-velocity sediments, lower-velocity sediments (1.5$3 \mathrm{~km} / \mathrm{s}$ ) cover the entire Central Basin. Their thickness is $\sim 3 \mathrm{~km}$ at the center of the basin, $2-3 \mathrm{~km}$ at the Selenga Delta, $1-1.5 \mathrm{~km}$ at the Barguzin Delta, and $\sim 2 \mathrm{~km}$ at the southern part of the Northern Basin.

[13] Severe attenuation of seismic energy and anomalously low apparent velocities within the shallow sedimentary section are apparent in two OBS records (wide-angle data from OBS AA3 and B1, not shown) south of Ol'khon Island that were recorded with two different active source configurations (Figure 3). The coincident MCS profile at km 100-125 along the model profile shows chaotic or disrupted reflections capped by a reflector with reverse polarity (Figures 8 and 3b, shots 4100-4450, of Hutchinson et al. [1992]). The above seismic characteristics are interpreted to represent free gas, possibly resulting from discharge of methane gas in the central part of the Central Basin due to rapid sediment influx from the Selenga Delta. A bottomsimulating reflector (BSR) extends from the gas pocket northward along the Central Basin (Figure 8). A BSR with reverse polarity indicating the presence of free gas was also observed south of the Selenga Delta [Vanneste et al., 2001].

\subsection{Crust}

[14] Crustal and Moho reflections and crustal refractions are observable at offsets ranging from 25 to $170 \mathrm{~km}$ 

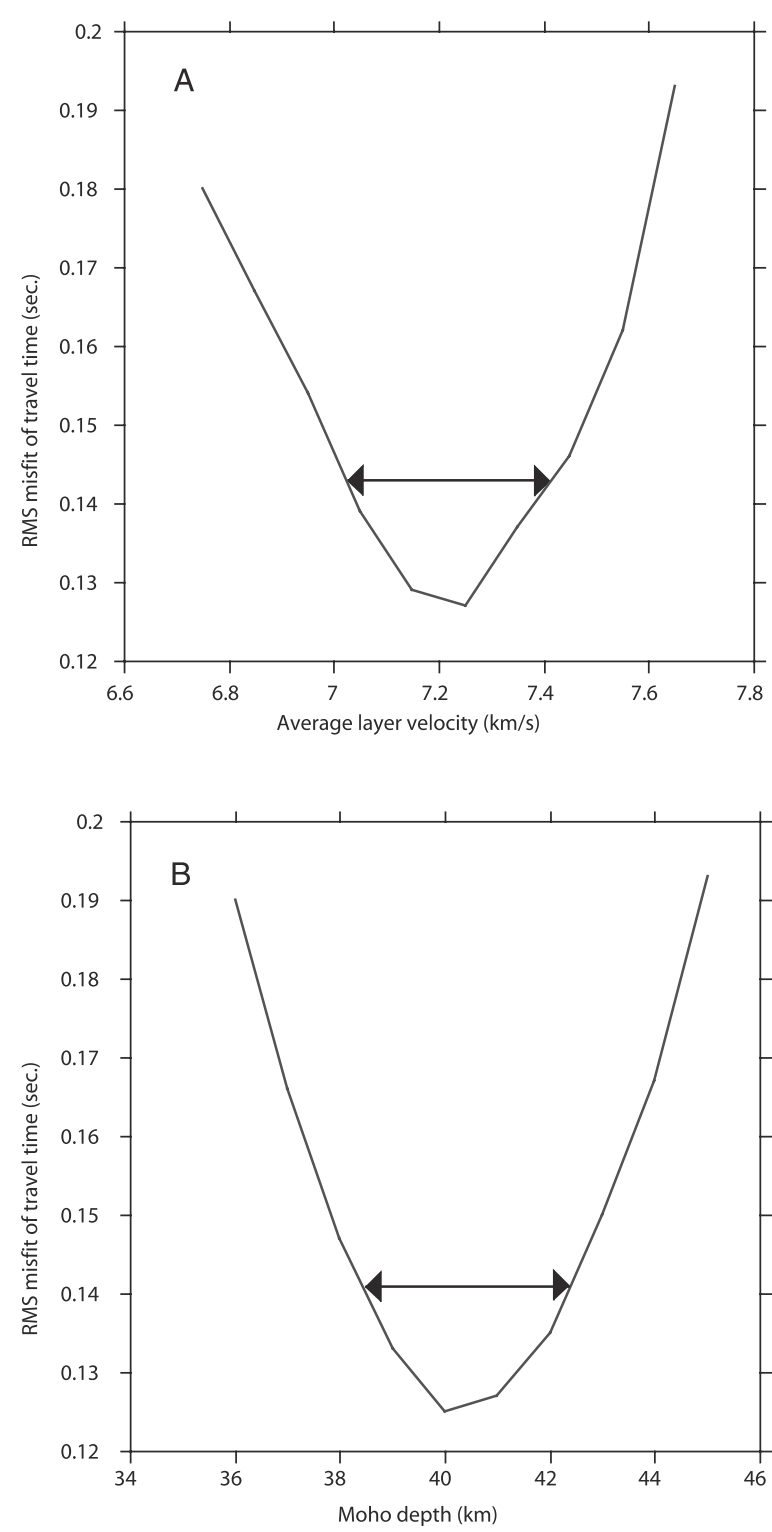

Figure 6. Perturbations to the best fitting model shown in Figure 7. Moho depth was varied in increments of $1 \mathrm{~km}$, and the average velocity of the basal layer was varied in increments of $0.1 \mathrm{~km} / \mathrm{s}$, with a constant velocity difference of $1 \mathrm{~km} / \mathrm{s}$ between the top and bottom of the layer. The purpose of these perturbations was to explore the range of permissible solutions. Using the $F$ test as a guide, we determine a velocity range (shown by arrows) of 7.05$7.4 \mathrm{~km} / \mathrm{s}$ and a depth range to Moho of $39-42.5 \mathrm{~km}$.

(Figure 4). The subsedimentary continental crust in our model consists of three layers, with velocities ranging from 5.6 to $7.2 \mathrm{~km} / \mathrm{s}$ (Figure $7 \mathrm{a}$ ). Variations in upper crustal velocity gradient along the profile are reflected in the thickness of the top layer and show the highest gradient to be located under the Selenga Delta. Upper crust is defined by velocity values ranging from 5.6 to $6.3 \mathrm{~km} / \mathrm{s}$. $P$ wave velocities for the midcrustal layer range from 6.4 to $6.9 \mathrm{~km} / \mathrm{s}$. The lower crustal layer has a uniform thickness of $\sim 8 \mathrm{~km}$, beginning at a depth of $\sim 33 \mathrm{~km}$ with an average $P$ wave velocity of $7.2 \mathrm{~km} / \mathrm{s}$ (Figure 7a). The apparent highvelocity layer occurs throughout the entire model and is associated with wide-angle reflections $(P 3 P)$ from its top surface (Figure 4). Average depth to Moho is $\sim 40 \mathrm{~km}$, with small wavelength perturbations incorporated into the model to fit the observed travel times. PmP (wide-angle reflection from the Moho) and $P n$ (refraction from the uppermost mantle) arrivals are only constrained in the central portion of the model at $\sim 75-155 \mathrm{~km}$. Both arrivals display reciprocity in OBS records from the southern and northern extents of the survey (Figure 5). $P n$ velocity is $8.0 \mathrm{~km} / \mathrm{s}$.

[15] To test the accuracy of our model, we perturbed the best fitting model by changing Moho depth by $1-\mathrm{km}$ increments and by changing the basal layer velocity by $1 \mathrm{~km} / \mathrm{s}$ increments and keeping a constant velocity gradient within the basal layer. The variances of these perturbations were computed (Figure 6). Next, we estimated the ranges of velocities and depths that satisfy the seismic observations. Under the assumption of Gaussian distribution of the residual travel time we can use the $F$ test. If the difference in RMS value between the best fitting model and the perturbed model is $\geq 0.01 \mathrm{~s}$, then the perturbed model is different at the $99 \%$ confidence level. For the subset of rays that penetrate the lower crust a difference in RMS value $\geq 0.015$ s (i.e., an RMS value of $0.142 \mathrm{~s}$ ), implies that the perturbed model is different at a $99 \%$ confidence level from the best fitting model. Hence we estimate the range of lower crustal velocities at $7.05-7.4 \mathrm{~km} / \mathrm{s}$, and the range of Moho depths is estimated at $39-42.5 \mathrm{~km}$. We cannot confidently assign error bounds to upper mantle velocity due to the small number of $P n$ arrivals.

[16] Our lower crustal velocity and Moho depth are significantly different from previously published wideangle seismic reflection and refraction results [Krylov, 1981; M. M. Mandelbaum et al., Deep structure of the region, unpublished manuscript, 2001], which were based on data from sparse shots and receivers, none of which were located within the lake. Their models probably did not incorporate near-surface and shallow structural constraints because of lack of coincident MCS data. According to Krylov [1981] and M. M. Mandelbaum et al. (Deep structure of the region, unpublished manuscript, 2001) Moho is $34-38 \mathrm{~km}$ deep beneath the Central Basin, increasing abruptly to $42-44 \mathrm{~km}$ in the Northern and Barguzin Basins. It is $36-37 \mathrm{~km}$ deep beneath the Selenga Basin. They report relatively low basal velocity of the crust $(6.4 \mathrm{~km} / \mathrm{s})$ under all the basins and a relatively lowvelocity upper mantle layer $(7.6-7.8 \mathrm{~km} / \mathrm{s})$ that extends under the entire length of Lake Baikal and for another 100-150 km southeastward underneath Transbaikal. An additional interface was placed at depths of 55-60 km where velocity increased to $8.2-8.3 \mathrm{~km} / \mathrm{s}$. Error bounds of previous measurements in the Baikal rift zone were estimated as $\pm 2 \mathrm{~km}$ for Moho depth and $\pm 0.2-0.3 \mathrm{~km} / \mathrm{s}$ for upper mantle velocity (M. M. Mandelbaum et al., Deep structure of the region, unpublished manuscript, 2001). Krylov's [1981] results were used to argue for an active upwelling driving force for Baikal rifting [e.g., Zorin et al., 1989]. However, considering the error bars on the above velocities and using our own results for $P n$ velocities, it is unclear whether an upper mantle velocity anomaly exists under Lake Baikal. 

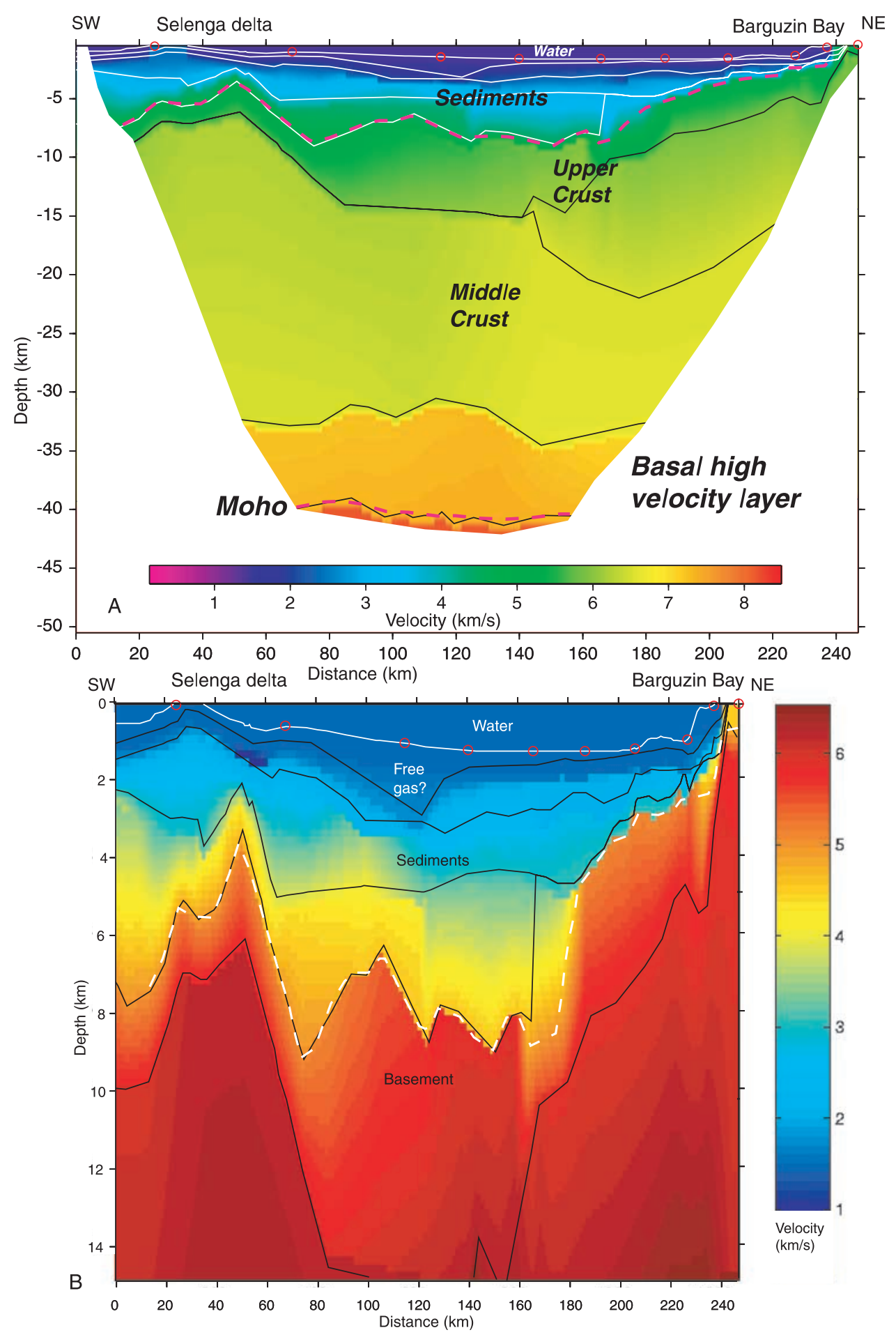

Figure 7. (a) $P$ wave velocity model along the Central Baikal Basin (gray line in Figure 3). (b) An enlargement of the upper part of the model. Red circles indicate locations of ocean bottom seismometers.

[17] Our Moho depth and $P n$ velocity are also different from the Gao et al. [1994] interpretation of teleseismic $P$ wave travel time delays observed in a profile across the Central Basin. Assuming that the delay arises from structure on the lithosphere-asthenosphere boundary, they concluded that the asthenosphere reaches a level as shallow as $34 \mathrm{~km}$ under the Central Basin and has a velocity contrast of $-5 \%$ with the lithosphere (i.e., a velocity of $7.7 \mathrm{~km} / \mathrm{s}$ ). The Gao et al. [1994] interpretation was challenged by Petit et al.
[1998], who proposed a different distribution of travel time delays within the upper mantle.

\section{Discussion}

\subsection{Rifting Mechanisms}

[18] Our seismic velocity structure for the Central Basin (Figure 7) is characterized by (1) a Moho depth of 39$42.5 \mathrm{~km}$, (2) an 8-km-thick, laterally continuous high- 

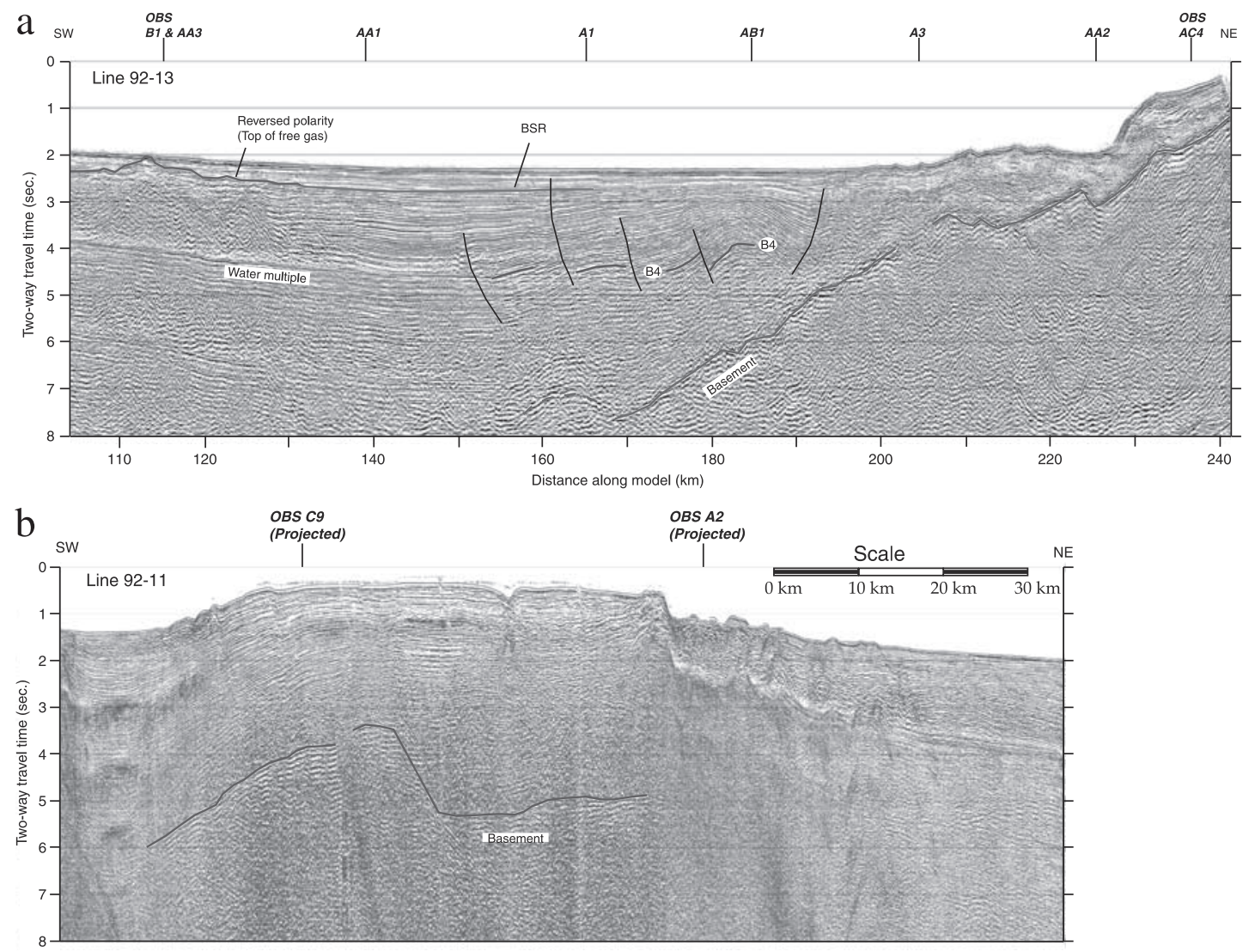

Figure 8. Seismic reflection lines (a) $92-13$ and (b) $92-11$ along the Central Basin. Line $92-13$ is coincident with part of the refraction line, but line 92-11 is not. See Figure 3 for location. The deeper sedimentary section on line 92-13 is nonreflective for reasons that are not entirely clear, but not because of the water multiple [Lee et al., 1996]. Basement is deeper than $8 \mathrm{~s}$ under the deepest part of the basin and rises toward Barguzin Bay and under the Selenga Delta, as indicated by the velocity model. The hummocky character of the reflectors at $\mathrm{km} \mathrm{105-132} \mathrm{is} \mathrm{likely} \mathrm{due} \mathrm{to} \mathrm{the} \mathrm{presence} \mathrm{of} \mathrm{free} \mathrm{gas} \mathrm{in} \mathrm{the}$ sediments. Reversed polarity of the top reflector and severe attenuation of the refraction records of OBS $\mathrm{B} 1$ and AA3 at this location (Figure 5) support this interpretation. A bottom-simulating reflector extends northeastward along the line and is associated with normal polarity. B4 is stratigraphic horizon identified by Moore et al. [1997].

velocity $(7.05-7.4 \mathrm{~km} / \mathrm{s})$ lower crust, (3) a sedimentary section reaching maximum depths of $9 \mathrm{~km}$, and (4) sediment velocity increasing gradually with depth, probably with a normal $P n$ velocity of $\sim 8 \mathrm{~km} / \mathrm{s}$.

[19] The high-velocity basal crustal layer can be interpreted in two ways, either as rift-related magmatic addition to the base of the crust or as relic prerift continental crust. Travel time delays of teleseismic data indicate that the asthenosphere under the rift is not much deeper than the base of the crust [Gao et al., 1994; Rogozhina and Kozhevnikov, 1979], although later work [Petit et al., 1998] and our $P n$ velocity questioned this result. A shallow asthenosphere could be a potential source for magmatic addition to the base of the crust in the form of dikes [Zorin et al., 1989] or sills. A basal high-velocity layer was found under other rifts, for example, under the Oslo Graben, which is a narrow Middle to Late Paleozoic rift within Precambrian crust [Newmann et al., 1995] similar to Lake Baikal. Unlike Lake Baikal, however, the basal layer is associated with extensive basaltic to rhyolitic volcanoes and shallow intru- sions in the form of dikes and sills, which were emplaced throughout the rifting history [Newmann et al., 1995]. In addition, the crust under the Oslo Basin was thinned considerably with a Moho depth at $32 \mathrm{~km}$ and the top of the basal layer at $20 \mathrm{~km}$ depth [Newmann et al., 1995]. There is no evidence for Cenozoic volcanism in and around the Central Basin or in other parts of Lake Baikal [Kiselev, 1987].

[20] Volcanism in the Baikal rift system is, in fact, rarely associated with the basins themselves. Volcanic rocks at the Sayan-Khamar Daban area west of Lake Baikal are found mostly outside the basins and extend hundreds of kilometers south into Mongolia (Figure 1) [Kiselev and Popov, 1992; Windley and Allen, 1993]. Volcanism east of Lake Baikal is confined to the Vitim Plateau and Udokan Range, elevated areas south of the rift system. The largest volume of volcanism erupted during the Miocene, although volcanism continued into the Pleistocene [Kiselev and Popov, 1992]. Mantle xenoliths in young (1-4 Ma) volcanic rocks SW of Lake Baikal have chemical composition and texture similar 


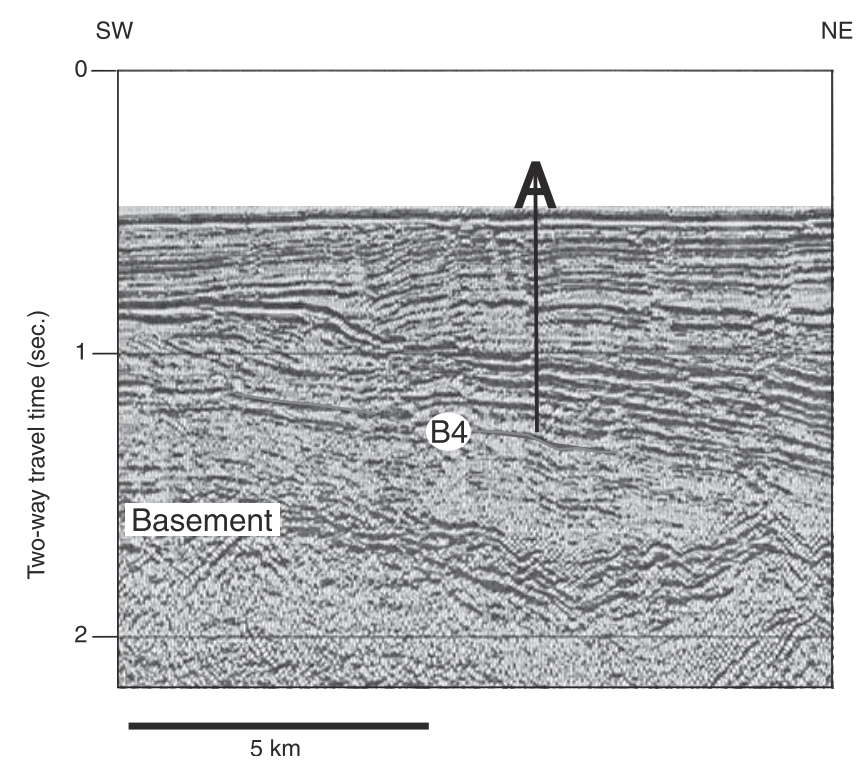

Figure 9. A portion of seismic reflection line 92-15 along the Academic Ridge in the vicinity of boreholes BDP-98. See Figure 3 for location. B4 is the stratigraphic horizon identified by Moore et al. [1997], which is close to the bottom of the hole. Age of sediments at the bottom of the hole is identified at $11 \mathrm{Ma}$ (J. King, personal communication, 2000).

to xenoliths in older (5-7 Ma) eruptions. Their equilibrium temperatures do not indicate progressive shallowing of the level of magma generation [Ionov et al., 1995; Kiselev and Popov, 1992]. These temperatures are not particularly high, arguing against anomalous mantle temperatures or partial melt beneath the rift zone [Ionov et al., 1995]. We therefore do not interpret the basal high-velocity layer as representing magmatic addition to the lower crust during rifting.
[21] The alternative interpretation for the high-velocity basal layer is that it is a relic of the prerifted crust. The velocity structure of the Siberian Platform derived from Russian transcontinental refraction lines is characterized by a $P$ wave velocity of $7.2-7.4 \mathrm{~km} / \mathrm{s}$ in the lower $10 \mathrm{~km}$ of the crust and a Moho depth of 40-42 km [Pavlenkova, 1996]. Logatchev and Zorin [1992] hypothesized the existence of mafic lower crust in the Baikal region, which consists of the differentiation products of large Precambrian and lower Paleozoic granitic bodies. World-wide compilation of crustal velocity structure shows that a basal layer velocity of $7-$ $7.3 \mathrm{~km} / \mathrm{s}$ is typical of Proterozoic shields and platforms and of continental arcs [Christensen and Mooney, 1995]. In particular, the average layer thickness of Proterozoic shields and platforms is $7 \mathrm{~km}$, and the average Moho depth is $41.5 \mathrm{~km}$ [Christensen and Mooney, 1995], although variations from the average can be large [Durrheim and Mooney, 1991]. We therefore propose that the lower part of the crust under Lake Baikal is a remnant of the original crust of the Siberian Platform or of continental arcs within the SayanBaikal belt.

[22] If we accept this interpretation, then rifting of Central Baikal Basin must be confined to the upper and middle crust, whereas the lower crust and Moho are not modified to a degree that can be detected seismically (Figure 10). One way to achieve this style of rifting is by extension along a normal fault, which flattens into a midcrustal detachment. Krylov et al. [1993] present a line drawing from a deep seismic reflection profile along the Upper Angara Basin (north of Lake Baikal) that shows a band of reflectivity extending from the upper crust to a depth of $18-22 \mathrm{~km}$ where it flattens. The interpretation of Baikal rift basins as narrow rifts rooted into midcrustal detachments (Figure 10) is also attractive given that the basins occupy the Sayan-Baikal fold-and-thrust belt at its boundary with the Archean-Proterozoic crust of the Siberian Platform (Figure 2) [e.g., Zamarayev and Ruzhich, 1978].

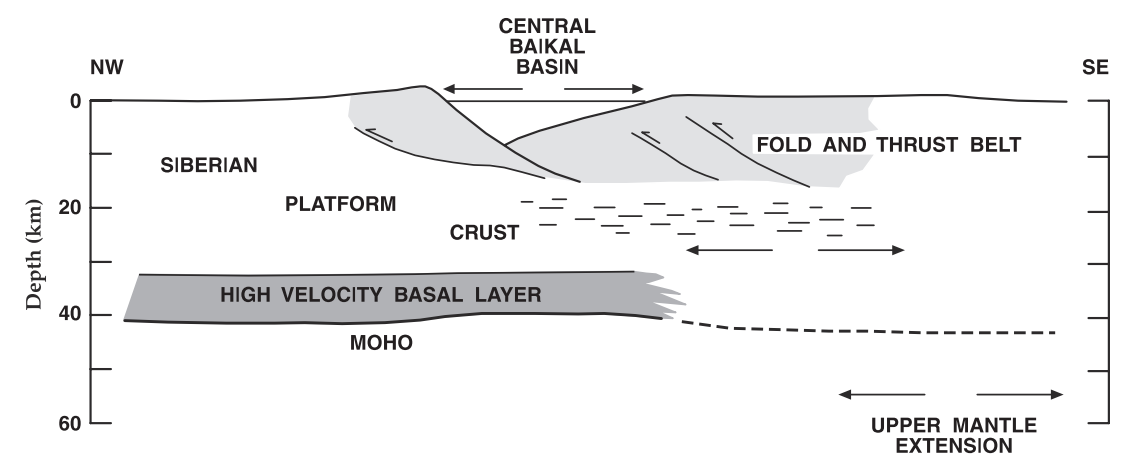

Figure 10. Conceptual model for the extension of the Central Basin. Rifting of the Central Basin is confined to the upper and middle crust and probably reactivates one of the faults within the fold and thrust belt, which was accreted during the Late Proterozoic and the Paleozoic onto the Siberian Platform. The lower crust and Moho are not modified to an extent that can be detected seismically. This style of rifting can be achieved by extension on faults soling into a midcrustal detachment. Krylov et al. [1993] presents a line drawing from a deep seismic reflection line in the upper Angara region showing a band of reflectivity extending from the upper crust and flattening at depths of $18-22 \mathrm{~km}$. The locus of upper mantle extension is possibly shifted to the southeast where high topography, volcanism, and, possibly, a thin astenosphere are observed. 
[23] Poort et al. [1998] and van der Beek [1997] proposed a detachment model to explain the topography and gravity fields across the Central Basin. They used timedependent thermomechanical models in which extension takes place along a listric normal fault that flattens at a depth of $20 \mathrm{~km}$ and by pure shear in the lower crust and upper mantle. Their models predicted the Moho under the rift to shallow by $3 \mathrm{~km}$, which is within our error estimates. The required thinning factor in their model is small $(\beta=$ 1.3 ), and therefore the expected thermal and mechanical perturbations are small. They and others [e.g., Ruppel et al., 1993] estimated the elastic thickness of the lithosphere to be large $(30-50 \mathrm{~km})$ implying a rigid cold lithosphere. The large depth of some earthquakes, $25-30 \mathrm{~km}$, also implies a cold crust [Deverchère et al., 1993]. Our interpretation of a Siberian Platform crust underlying the rift is consistent with these observations, although we cannot determine whether the faults are listric and whether upper mantle extension occurs under the lake.

[24] The van der Beek [1997] model assumes that upper mantle extension occurs under the rift. Alternatively, the locus of upper mantle extension could be offset from the rift (Figure 10), as was proposed for the Atlantic margin of North America [Dunbar and Sawyer, 1989; Braun and Beaumont, 1989; Harry and Sawyer, 1992]. Harry and Sawyer [1992] suggested that upper crustal extension during the first $50 \mathrm{~m}$.y. of rifting resulted from reactivation of the thin-skinned Appalachian fold-and-thrust belt over a cold lithosphere, while upper mantle extension took place 200-300 km seaward. During the $10 \mathrm{~m} . \mathrm{y}$. prior to the initiation of seafloor spreading in the Atlantic Ocean, crustal extension shifted to the location of upper mantle extension as asthenospheric upwelling thermally weakened the overlying crust.

[25] The Baikal rift system is similar in many respects to the Triassic-Jurassic Atlantic rift system.

1. The Atlantic rift system followed the sinuous Paleozoic suture between the African and North American continents far from active plate boundaries at that time (Figure 11) [e.g., Manspeizer and Cousminer, 1988]. This distribution is reminiscent of the distribution of Baikal rift basins along the sinuous Sayan-Baikal fold-and-thrust belt.

2. The Atlantic rift system consists of numerous rift basins with a mixture of shapes and sizes. They are not arranged along a narrow axis (i.e., the rift valley) and some basins are even sub-parallel to one other within the suture zone. A similar mixture of shapes and size of basins and a similar non-axial arrangement characterize the Baikal rift system. Barguzin Basin is subparallel to the North Basin as are some of the smaller basins north of Lake Baikal. In both rift systems the location of the basins probably follows upper crustal weaknesses in the form of pre-existing thrust sheets within the Paleozoic fold-and-thrust belt.

3. The Newark basin (Figure 11), a large (220 by $50 \mathrm{~km})$ and deep $(>7.5 \mathrm{~km})$ basin within the Atlantic rift system, was connected to the Gettysburg and Culpepper Basins to the south via narrow necks creating an elongated lake much like Lake Baikal [Olsen et al., 1996]. All three basins have their major border fault on the NW side.

4. The first 25-30 m.y. of rifting in the Newark Basin were nonvolcanic [Manspeizer and Cousminer, 1988].
5. Deep seismic reflection and refraction profiles under other Triassic-Jurassic basins of the Atlantic continental margin show that Moho depth is not elevated under those basins [Johnson et al., 1998; Nelson et al., 1985].

6. A pervasive hydrothermal convection system circulated relatively high-temperature fluids within the basin during rifting despite the lack of a shallow mantle source [Steckler et al., 1993]. High geothermal gradients in Lake Baikal initially interpreted to reflect shallow mantle sources [Zorin and Lepina, 1985] can also be explained by hydrothermal circulation of meteoric water [Golubev, 1990].

[26] The architecture of the Baikal rift system is, in fact, different from many other continental rift systems to which it had been previously compared [Kazmin, 1991; Lipman et al., 1989; Lysak, 1987; Zorin and Lepina, 1985]. Basins within the East Africa rift system, the Ethiopian Rift, the Rio Grande Rift and the Gulf of Suez are arranged along a narrow long axis (the rift valley). The differences between the Baikal rift system and the above rift systems are perhaps related to the location of upper mantle extension and thermal perturbation relative to the location of the crustal rift in light of suggestions for mantle upwelling southeast [Kazmin, 1991; Kiselev and Popov, 1992; Windley and Allen, 1993] or northwest [Petit et al., 1998] of Baikal rift zone. Alternatively, the differences may be attributed to the alignment of the former compression and present extension directions [e.g., Zonenshain et al., 1990], which enables extension by fault reactivation across the width of the fold-and-thrust belt. In summary, we believe that a thin-skinned extension model for the upper crust with an offset separating the loci of upper crust and upper mantle extension may apply to the development of the Baikal rift.

[27] Other mechanical models have recently been suggested to explain the gravity and topography fields across Lake Baikal and, in particular, its uplifted margins. Petit et al. [1997] modeled the gravity field by a rigid plate with discontinuities at the NW and SE sides of the Central Basin. The Siberian and Transbaikal plates in their model are downwarped toward the rift, and the crust beneath the uplifted margins is thickened. The basin is thereby effectively in local isostatic equilibrium, and Moho under the rift is predicted to warp up by $7 \mathrm{~km}$ relative to the Siberian Platform [Petit et al., 1997]. The difference between the Moho depth of our model and of the Siberian Platform [Pavlenkova, 1996] is only $3 \mathrm{~km}$ or less. Moreover, there is no geological evidence for a lithospheric-scale discontinuity SE of the lake [Petit et al., 1997].

[28] Lesne et al. [2000] fit the basin subsidence and the surrounding uplifted shoulders by a mechanical finite element model with layered rheology, in which extension takes place on a normal fault cutting the entire lithosphere. Their model generates the observed subsidence and uplift in only 2.5-3.5 m.y, which they attribute to the "fast rifting stage." In section 5.2 we argue that the Central Basin and probably also the Northern Basin are much older than $3 \mathrm{Ma}$ and that there is no clear evidence for a fast rifting stage starting at $3 \mathrm{Ma}$. In addition, their model generates a secondary basin $\mathrm{SE}$ of the main basin, which they interpret to represent the Barguzin Basin. However, the bounding fault in their model dips in the opposite direction to the bounding fault of the 

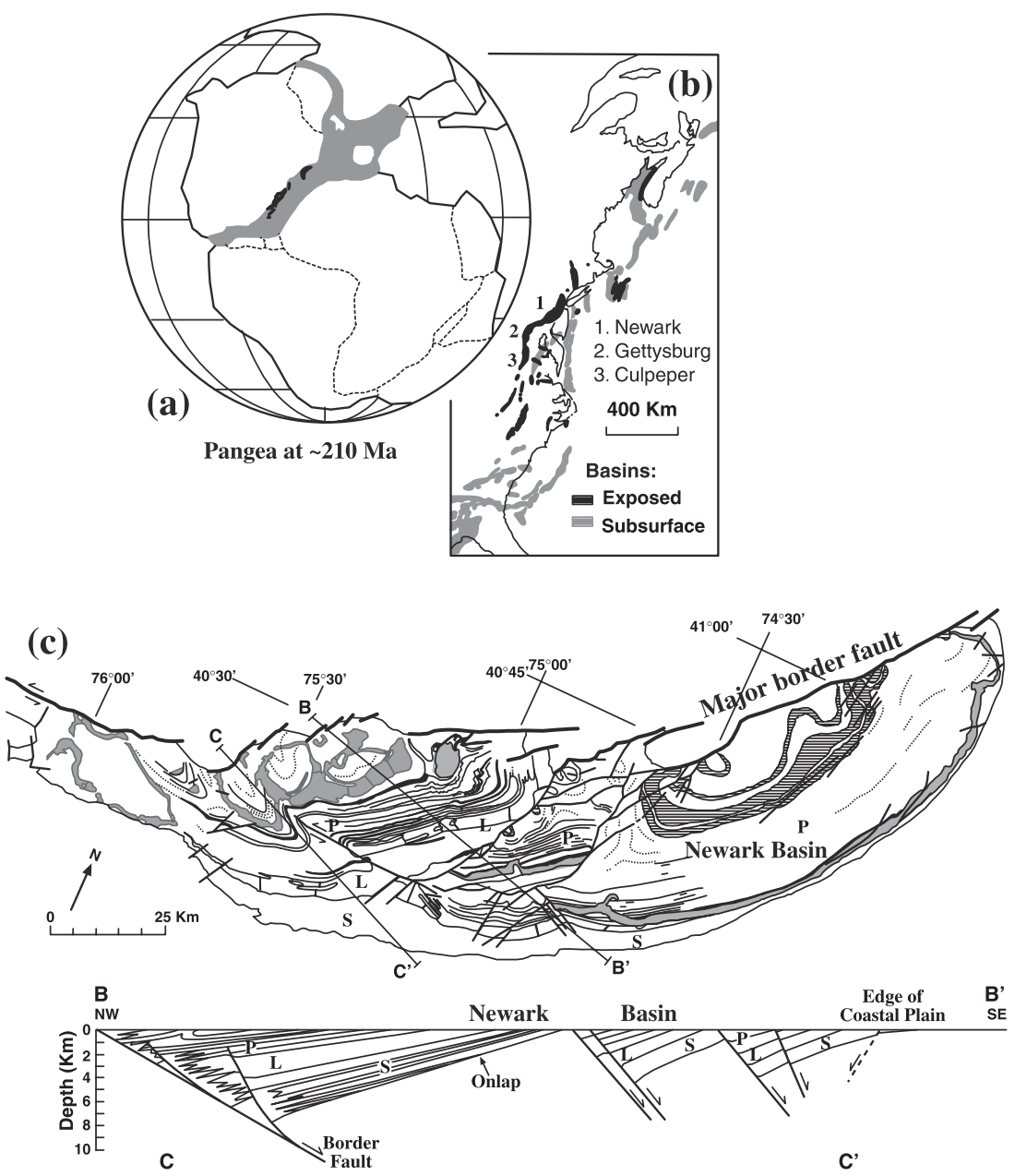

(d)

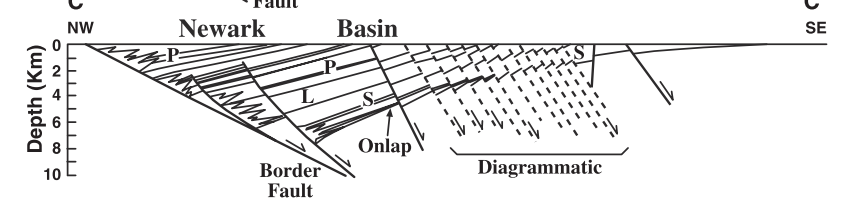

Figure 11. (a, b) Location of Atlantic rift system (black) within Pangea at $\sim 210 \mathrm{Ma}$ and the location of surface and subsurface basins of the Atlantic rift system along the Atlantic coast of the United States and Canada [after Olsen et al., 1996]. (c, d) Simplified geological map view and vertical cross sections of Newark Basin [after Schlische, 1992]. P and L are shallow and deepwater lacustrine strata, respectively, and $\mathrm{S}$ is fluvial sedimentary strata.

Barguzin Basin. There is no secondary basin SE of the Central Basin.

\subsection{Evolution of the Central Basin}

[29] Rifting of Baikal basins probably began during the middle Oligocene ( $\sim 35 \mathrm{Ma})$, although earlier (Paleocene to early Eocene) lacustrine and alluvial sediments were found at the bottom of boreholes in the Selenga Delta [Mats, 1993]. Where exposed or drilled, the Oligocene to Pliocene sediments often comprise alternating beds of clay, siltstones, and sand deposited in a lacustrine environment [Mats, 1993]. Rifting is generally considered to have intensified since the middle Pliocene ( $\sim 3 \mathrm{Ma})$ because Pliocene and younger sediments consist of coarser sands, argillites, and silts, indicating the intensification of the topographic relief, and because of a perceived increase in sedimentation rate
[Logatchev and Zorin, 1987; Delvaux et al., 1997; Kazmin et al., 1995; Mats, 1993]. Here we argue against the existence of rift-wide stages and for episodic subsidence and enlargement of individual subbasins, as is observed in other rift basins [e.g., Ebinger et al., 1989].

[30] Borehole BDP96 on Academic Ridge (Figure 3) yielded an age of $5 \mathrm{Ma}$ at a depth of $192 \mathrm{~m}$ subbottom based on a magnetic polarity stratigraphy and a nearly constant sedimentation rate of $4 \mathrm{~cm} / \mathrm{kyr}$ without major hiatuses or disconformities [Williams et al., 1997]. The composition and texture of sediments are remarkably uniform throughout the borehole, indicating that the present hemipelagic lacustrine facies has persisted during the past 5 m.y. on Academic Ridge [Kuzmin et al., 2000]. An adjacent hole, BDP98, yielded a paleomagnetic age of $11 \mathrm{Ma}$ at a depth of $650 \mathrm{~m}$ subbottom and did not appear 
to have major hiatuses (J. King, personal communication, 2000). This depth is equivalent to $795 \mathrm{~ms}$ two-way travel time (TWTT), using an average velocity of $1.67 \mathrm{~km} / \mathrm{s}$ (C. Scholz, personal communication, 2000). An MCS profile adjacent to these boreholes (Figure 9) shows reflective sedimentary section down to $\sim 800 \mathrm{~ms}$ subbottom, where a horizon, labeled B4 by Moore et al. [1997], is observed. The underlying $420 \mathrm{~ms}$ to basement in this profile lack continuous reflections. A horizon interpreted to be equivalent to B4 in the Central Basin was identified close to the water multiple at TWTT of 4-4.5 s (Figure 8) [Moore et al., 1997], which corresponds to a depths of $2.4-2.9 \mathrm{~km}$ subbottom assuming average velocities of $2.25-2.5 \mathrm{~km} / \mathrm{s}$ (Figure 7b).

[31] Hutchinson et al. [1992] interpreted the reflective sedimentary section above $4 \mathrm{~s}$ TWTT to have been deposited since middle Pliocene. If the stratigraphic correlation between the Academic Ridge and the Central Basin is correct, then the reflective upper sedimentary unit in the Central Basin was deposited over much longer time period than previously assumed [Hutchinson et al., 1992], at least since $11 \mathrm{Ma}$. In addition, changes in reflectivity with depth were shown in later work to be gradual and explained by diagenesis [Lee et al., 1996]. Our wide-angle reflection data show no evidence for a regional reflecting horizon within the sedimentary section.

[32] Assuming an age of $11 \mathrm{Ma}$ at this depth, the average sedimentation rate for the northern part of the Central Basin (uncorrected for compaction) is $22-26 \mathrm{~cm} / \mathrm{kyr}$. Slow continuous deposition is also observed in the Newark Basin, where $6700 \mathrm{~m}$ of lacustrine sediments were deposited over 24 m.y. [Olsen et al., 1996] an average of $28 \mathrm{~cm} / \mathrm{kyr}$. On Academic Ridge the average sedimentation rate for the past $11 \mathrm{~m} . \mathrm{y}$. is 1.5 times faster than the average rate for the past 5 m.y., and sedimentation rate for the past 5 m.y. has been almost uniform [Williams et al., 1997]. Sedimentation rate in the Selenga Delta during the Holocene and during past $650 \mathrm{kyr}$ is similar, $15-20 \mathrm{~cm} / \mathrm{kyr}$ [Scholz and Hutchinson, 2000; Colman et al., 1996]. Sedimentation rate in the southwestern part of the Northern Basin during the last $2.5 \mathrm{~m} . \mathrm{y}$. was estimated to be much higher, $60-70 \mathrm{~cm} / \mathrm{kyr}$ [Kuzmin et al., 2000] based on the correlation of a prominent unconformity there with a reflector near borehole BDP96 (Horizon B-10 [Moore et al., 1997]). However, this correlation was based solely on the assumption that prograding clinoforms in these two areas, which are $50 \mathrm{~km}$ apart, have the same age [Moore et al., 1997]. More generally, equating changes in sedimentation rate with changes in subsidence rate, can be problematic, because sedimentation rate depends on sediment supply, which is spatially and temporaly variable within the lake environment.

[33] We also see no clear indication for a fast rifting stage starting $3 \mathrm{~m} . \mathrm{y}$. ago in the initiation of subsidence of new basins. The age of the Northern Basin is estimated to be 6.6 Ma [San'kov et al., 2000], late Miocene [Kazmin et al., 1995], 14 Ma (S. M. Colman et al., Quaternary depositional patterns and environments in Lake Baikal from high-resolution seismic stratigraphy and coring, unpublished manuscript, 2001), or the same as the age of the Central Basin [Moore et al., 1997]. The estimated age of different basins north of Lake Baikal ranges between 1 and $7 \mathrm{Ma}$ [San'kov et al., 2000]. More generally, equating changes in subsi- dence rate with changes in extension rate can also be problematic.

[34] Growth of normal faults by linking isolated fault segments and the cessation of movement on other fault in stress shadow zones of the newly linked faults can lead to episodes of rapid local subsidence and to the enlargement and coalescence of existing basins [Gupta et al., 1998]. This can lead to changes in sediment transport paths. Indeed, where documented, increasing subsidence rate has been episodic and has not been coeval even across short distances. For example, an episode of rapid subsidence started 650 kyr ago in the Selenga Delta (S. M. Colman et al., Quaternary depositional patterns and environments in Lake Baikal from high-resolution seismic stratigraphy and coring, unpublished manuscript, 2001) and rapid subsidence of the Selenga Basin occurred 1.7-1.4 m.y. ago [Scholz and Hutchinson, 2000]. Both locations are underlain by thick (4-8 km) sedimentary sections, which have been subsiding long before the late Pleistocene. Seismic stratigraphy (Figure 8) [Moore et al., 1997] indicates that the Central Basin grew northward with time, probably during the Late Miocene [Kazmin et al., 1995; Mats, 1993]. In our velocity model, high-velocity sediments are confined to the deep portion of the basin, whereas lower-velocity sediments extend over the entire basin length (Figure 7b). Agar and Klitgord [1995] documented a southward propagation of Primorskiy Fault, probably within the last 1 m.y. An embayment, Maloy More, and a subaerial graben, which connect to the Northern Basin, were formed in the wake of this propagation [Agar and Klitgord, 1995].

\section{Conclusions}

[35] Results from a wide-angle seismic reflection and refraction profile along the Central Basin of Baikal rift show that the base of the sedimentary section reaches a depth of 8-9 $\mathrm{km}$ beneath the Central Basin and shallows toward Barguzin Bay and under the Selenga Delta. The crust includes an 8-km-thick basal high-velocity ( $\sim 7.2-$ $7.3 \mathrm{~km} / \mathrm{s}$ ) layer. The Moho is $\sim 40 \mathrm{~km}$ deep, and upper mantle velocity is probably normal. We believe that the high-velocity basal layer does not represent rift-related magmatic addition to the lower crust because there is no geological evidence for volcanism in the Central Basin, in contrast to other rifts with a magmatic layer (Oslo Graben, West Antarctica). In fact, Baikal rift volcanism occurs mainly outside the rift basins, often in areas of high topography, and it extends hundreds of kilometers to the south. In addition, the largest volume of Baikal volcanism occurred during the Miocene, and xenoliths do not show progressive shallowing of the melt region with time. The inferred mantle temperature is not particularly high, and the elastic thickness of the lithosphere is indicative of a cold lithosphere. We interpret the basal layer as a relic of the prerift crust, most likely a relic of the Siberian Platform. Crustal structure of the Siberian Platform is characterized by a $10-\mathrm{km}$-thick basal layer with velocities of $7.2-7.4 \mathrm{~km} / \mathrm{s}$ and a Moho depth of $42 \mathrm{~km}$. World-wide compilations of $P$ wave velocities in continental crust shows that such a highvelocity basal layer is typical of shields and platforms.

[36] This interpretation implies that rifting of the Central Basin is confined to the upper and middle crust, whereas 
the lower crust is not modified to an extent that can be detected seismically. This style of rifting can be achieved by normal faults soling into a midcrustal detachment. Krylov et al. [1993] present a line drawing from a deep seismic reflection line in the upper Angara region showing a band of reflectivity extending from the upper crust and flattening at depths of $18-22 \mathrm{~km}$, which may emanate from this detachment.

[37] The locus of upper mantle extension is possibly shifted to the southeast of Baikal rift zone where high topography, volcanism, and, according to some, a thin asthenosphere are observed. A similar rifting model was proposed for the Triassic-Jurassic rift system along the Atlantic margin of North America. In this model, upper crustal extension utilized preexisting zones of weakness, whereas upper mantle extension occurred 200-300 km seaward. Many aspects of the geometry, distribution, and crustal structure of the Atlantic rift system are similar to the Baikal rift system.

[38] We question the common division of Baikal rift evolution into a fast rifting stage starting $\sim 3 \mathrm{Ma}$ and an earlier slower phase. Our seismic refraction model shows that sediment velocity increases gradually with depth and that there are no regional wide-angle reflections within the sediments to support an abrupt and major change in sedimentation. In addition, using the stratigraphic correlations of Moore et al. [1997], we suggest that the upper 2.4$2.9 \mathrm{~km}$ of sediments in the basin was deposited over at least 11 m.y., a much slower rate than previously assumed. We propose instead that rift evolution may be characterized by propagation and coalescence of boundary faults leading to local episodes of subsidence and to areal enlargement of basins.

[39] Acknowledgments. This project was jointly funded by the U.S. Geological Survey Coastal and Marine Program and the Russian Academy of Sciences. Debbie Hutchinson and Alexander Golmshtok coordinated the project. Logistical support was provided by Institutes of Limnology and of the Earth Crust in Irkutsk, the Listviyanka field office, and the Shirshov Institute of Oceanology in Gelenzhik. We thank Greg Miller, Alik Badardinov, Dwight Coleman, Mark Behrendt, and Captain A. Sakhalov and the crew of the R/V Titov for their dedicated field support of the OBS operation. We thank Alexander Golmshtok, Kim Klitgord, Chris Scholz, Liyosha Akentiev, and Dave Nichols for coordinating the shooting. Discussions with Steve Colman, Chris Scholz, John King, Kim Klitgord, and Debbie Hutchinson and helpful reviews by Steve Colman, Debbie Hutchinson, Cindy Ebinger, Jacques Deverchère, and an anonymous reviewer are gratefully acknowledged. Phil Molzer provided computer and graphical support.

\section{References}

Agar, S. M., and K. K. Klitgord, Rift flank segmentation, basin initiation and propagation: A neotectonic example of Lake Baikal, J. Geol. Soc. London, 152, 849-860, 1995.

Agena, W. F., M. W. Lee, J. J. Miller, and D. R. Hutchinson, Lake Baikal, 1992: Processing of multichannel seismic reflection data, U.S. Geol. Surv. Open File Rep., 94-0263, 37 pp., 1994.

Braun, J., and C. Beaumont, Dynamical models of the role of crustal shear zones in asymmetric continental extension, Earth Planet. Sci. Lett., 93, 405-423, 1989.

Burov, E. B., F. Houdry, M. Diament, and J. Deverchere, A broken plate beneath the Baikal rift zone revealed by gravity modelling, Geophys. Res. Lett., 21, 129-132, 1994.

Calais, E., and S. Amarjargal, New constraints on current deformation in Asia from continuous GPS measurements at Ulan Baatar, Mongolia, Geophys. Res. Lett., 27, 1527-1530, 2000.

Calais, E., O. Lesne, J. Deverchere, V. San'kov, A. Lukhnev, A. Miroshnitchenko, V. Buddo, K. Levi, V. Zalutzky, and Y. Bashkuev, Crustal deformation in the Baikal rift from GPS measurements, Geophys. Res. Lett., 25, 4003-4006, 1998.

Christensen, N. I., and W. D. Mooney, Seismic velocity structure and composition of the continental crust: A global view, J. Geophys. Res., 100, 9761-9788, 1995.

Colman, S. M., G. A. Jones, M. Rubin, J. W. King, J. A. Peck, and W. H. Orem, AMS radiocarbon analyses from Lake Baikal, Siberia: Challenges of dating sediments from a large oligotrophic lake, Quat. Sci. Rev., 15, 669-684, 1996.

Delvaux, D., R. Moeys, G. Stapel, C. Petit, K. Levi, A. Miroshnichenko, V. Ruzhnich, and V. San'kov, Paleostress reconstructions and geodynamics of the Baikal region, central Asia, part 2, Cenozoic rifting, Tectonophysics, 282, 1-38, 1997.

Deverchère, J., F. Houdry, N. V Solonenko, A. V. Solonenko, and V. S. Sankov, Seismicity, active faults and stress field of the North Muya region, Baikal rift: New insights on the rheology of extended continental lithosphere, J. Geophys. Res., 98, 19,895-19,912, 1993.

Doser, D. I., Faulting within the eastern Baikal rift as characterized by earthquake studies, Tectonophysics, 196, 109-139, 1991.

Dunbar, J. A., and D. S. Sawyer, How preexisting weaknesses control the style of continental breakup, J. Geophys. Res., 94, 7278-7292, 1989.

Durrheim, R. J., and W. D. Mooney, Archean and Proterozoic crustal evolution: Evidence from crustal seismology, Geology, 19, 606-609, 1991.

Ebinger, C. J., A. L. Deino, R. E. Drake, and A. L. Tesha, Chronology of volcanism and rift basin propagation: Rungwe volcanic province, East Africa, J. Geophys. Res., 94, 15,785-15,803, 1989.

Gao, S., P. M. Davis, H. Liu, P. D. Slack, Y. A. Zorin, N. A. Logatchev, M. G. Kogan, P. D. Burkholder, and R. P. Meyer, Asymmetric upwarp of the asthenosphere beneath the Baikal rift zone, Siberia, J. Geophys. Res., 99, 15,319-15,330, 1994.

Golubev, V.A., Hydrothermal systems, permeability and thermal models of the crust in the Baikal rift zone, Izv. Earth Phys., 26, 916-924, 1990.

Gupta, S., P. A. Cowie, N. H. Dawers, and J. R. Underhill, A mechanism to explain rift-basin subsidence and stratigraphic patterns through faultarray evolution, Geology, 26, 595-598, 1998.

Harry, D. L., and D. S. Sawyer, A dynamic model of lithospheric extension in the Baltimore Canyon Trough region, Tectonics, 11, 420-436, 1992.

Holbrook, W. S., and P. B. Kelemen, Large igneous province on the U.S. Atlantic margin and implications for magmatism during continental breakup, Nature, 364, 433-436, 1993.

Holbrook, W. S., T. M. Brocher, U. S. ten Brink, and J.A. Hole, Crustal structure of a transform plate boundary: San Francisco Bay and the central California continental margin, J. Geophy. Res., 101, 22,31122,334, 1996.

Hutchinson, D. R., A. J. Golmshtok, L. P. Zonenshain, T. C. Moore, C. A. Scholz, and K. D. Klitgord, Depositional and tectonic framework of the rift basins of Lake Baikal from multichannel seismic data, Geology, 20, 589-592, 1992

Ionov, D. A., S. Y. O'Reilly, and I. V. Ashchepkov, Feldspar-bearing lherzolite xenoliths in alkali basalts from Hamar-Daban, southern Baikal, Russia, Contrib. Mineral. Petrol., 122, 174-190, 1995.

Johnson, T. L., B. E. Wright, D. B. Stewart, and F. N. Zihlman, Global Geoscience Transect 8: Quebec-Maine-Gulf of Maine Transect, southeastern Canada, northern U.S.A., U.S. Geol. Surv. Misc. Invest. Ser. Map, I-2329, 1998.

Kazmin, V. G., The position of continental flood basalts in rift zones and its bearing on models of rifting, Tectonophysics, 199, 375-387, 1991.

Kazmin, V. G., A. Y. Golmshtok, K. Klitgord, T. Moore, D. Hutchinson, C. Scholz, and E. Weber, Structure and development of the Akademichesky Ridge area (Baikal rift) according to seismic investigations, Russ. Geol. Geophys., 36, 155-167, 1995.

Keller, G. R., M. H. P. Bott, R. F. Wendlandt, D. I. Doser, and P. Morgan, The Baikal rift system, in Continental Rifts: Evolution, Structure, Tectonics, edited by K. H. Olson, pp. 325-339, Elsevier Sci., New York, 1995.

Kiselev, A. I., Volcanism of the Baikal rift zone, Tectonophysics, 143, 235244, 1987.

Kiselev, A. I., and A. M. Popov, Asthenospheric diapir beneath Baikal rift: Petrological constraints, Tectonophysics, 208, 287-295, 1992.

Krylov, S. V., Nedra Bajkala, the Baikal Interior From Seismic Data, 105 pp., Trudy Inst. Geol. i Geofiz., Novosibirsk, Russia, 1981.

Krylov, S. V., Z. R. Mishenkina, Y. V. Kulchinskii, E. N. Ten, and I. F. Sheludko, Characteristics of seismoactive lithosphere for the northeast of Baikal region from data of detailed studies by DSS technique on $P$ - and S- waves, Russ. Geol. Geophys., 34, 110-119, 1993.

Kuzmin, M. I., E. B. Karabanov, A. A. Prokopenko, V. F. Gelety, V. S. Antipin, D. F. Williams, and A. N. Gvozdkov, Sedimentation processes and new age constraints on rifting stages in Lake Baikal: Results of deep water drilling, Int. J. Earth Sci., 89, 183-192, 2000. 
Lee, M. W., W. F. Agena, and D. R. Hutchinson, Amplitude blanking in seismic profiles from Lake Baikal, Mar. Pet. Geol., 13, 549-563, 1996.

Lesne, O., E. Calais, and J. Deverchere, Finite element modelling of crustal deformation in the Baikal rift zone: New insights into the active-passive debate, Tectonophysics, 289, 327-340, 1998

Lesne, O., E. Calais, J. Deverchere, J. Che'ry, and R. Hassani, Dynamics of intracontinental extension in the north Baikal rift from two-dimensional numerical deformation modeling, J. Geophys. Res., 105, 21,727-21,744, 2000.

Lipman, P. W., N. A. Logatchev, Y. A. Zorin, E. Chapin, V. Kovalenko, and P. Morgan, Intracontinental rift comparisons: Baikal and Rio Grande Rift systems, Eos Trans. AGU, 70, 578-579, 586-587, 1989.

Logatchev, N. A., and Y. A. Zorin, Evidence and causes of the two-stage development of the Baikal rift, Tectonophysics, 143, 225-234, 1987.

Logatchev, N. A., and Y. A. Zorin, Baikal rift zone: Structure and geodynamics, Tectonophysics, 208, 273-286, 1992.

Loss, J., I. A. Pecher, and U. S. ten Brink, RayGUI: A graphical user interface for interactive ray-tracing (rayinvr), U.S. Geol. Surv. Open File Rep., 98-203, 1998.

Lysak, S. V., Terrestrial heat flow of continental rifts, Tectonophysics, 143, $31-41,1987$.

Manspeizer, W., and H. L. Cousminer, Late Triassic-Early Jurassic synrift basins of the U.S. Atlantic margin, in The Geology of North America, Vol. I-2, The Atlantic Continental Margin, U.S., edited by R. E. Sheridan and J. A. Grow, pp. 197-216, Geol. Soc. of Am., Boulder, Colo., 1988.

Mats, V., The structure and development of Baikal rift depression, Earth Sci. Rev., 34, 81-118, 1993.

Moore, T. C., Jr., K. D. Klitgord, A. J. Golmshtok, and E. T. Weber, Sedimentation and subsidence patterns in the central and north basins of Lake Baikal from seismic stratigraphy, Geol. Soc. Am. Bull., 109, 746-766, 1997

Mutter, J. C., W. R. Buck, and C. M. Zehnder, Convective partial melting, 1, A model for the formation of thick basaltic sequences during the initiation of spreading, J. Geophys. Res., 93, 1031-1048, 1988.

Nelson, K. D., J. A. Arnow, J. H. McBride, J. H. Willemin, J. Huang, L. Zheng, J. E. Oliver, L. D. Brown, and S. Kaufman, New COCORP profiling in the southeastern United States, part I, Late Paleozoic suture and Mesozoic rift basin, Geology, 13, 714-718, 1985

Newmann, E. R., K. H. Olsen, and W. S. Baldridge, The Oslo rift, in Continental Rifts: Evolution, Structure, Tectonics, edited by K. H. Olsen, pp. 345-373, Elsevier Sci., New York, 1995.

Olsen, P. E., D. V. Kent, B. Cornet, W. K. Witte, and R. W. Schlische, Highresolution stratigraphy of the Newark rift basin, Geol. Soc. Am. Bull., 108, 40-77, 1996.

Pavlenkova, N. I., Crust and upper mantle structure in northern Eurasia from seismic data, Adv. Geophys., 37, 1-129, 1996

Petit, C., E. B. Burov, and J. Deverchere, On the structure and mechanical behavior of the extending lithosphere in the Baikal rift from gravity modelling, Earth Planet. Sci. Lett., 149, 29-42, 1997.

Petit, C., I. Koulakov, and J. Deverchere, Velocity structure around the Baikal rift zone from teleseismic and local earthquake traveltimes and geodynamic implications, Tectonophysics, 296, 125-144, 1998.

Poort, J., P. van der Beek, and M. ter Voorde, An integrated modelling study of the central and northern Baikal rift: Evidence for non-uniform lithospheric thinning, Tectonophysics, 291, 101-122, 1998

Rogozhina, V. A., and V. M. Kozhevnikov, Anomalous Mantle Area Beneath the Baikal Rift, 103 pp., Nauka, Novosibirsk, Russia, 1979.

Ruppel, C., Extensional processes in continental lithosphere, J. Geophys. Res., 100, 24,187-24,215, 1995.

Ruppel, C., M. G. Kogan, and M. K. McNutt, Implications of new gravity data for the Baikal rift zone structure, Geophys. Res. Lett., 20, 1635$1638,1993$.

San'kov, V., J. Deverchere, Y. Gaudemer, F. Houdry, and A. Filippov, Geometry and rate of faulting in the north Baikal rift, Siberia, Tectonics, 19, 707-722, 2000

Schlische, R. W., Structural and stratigraphic development of the Newark extensional basin: Evidence for the growth of the basin and its bounding structures, Geol. Soc. Am. Bull., 104, 1246-1263, 1992.

Scholz, C. A., and D. H. Hutchinson, Stratigraphic and structural evolution of the Selenga Delta accommodation zone, Lake Baikal rift, Siberia, Int. J. Earth Sci., 89, 212-228, 2000.

Scholz, C. A., K. D. Klitgord, D. H. Hutchinson, U. S. ten Brink, L. P. Zonenshain, A. Y. Golmschtok, and T. C. Moore, Results of 1992 seismic reflection experiment in Lake Baikal, Eos Trans. AGU, 74, 465, 469$470,1993$.

Steckler, M. S., G. I. Omar, G. D. Karner, and B. P. Kohn, Pattern of hydrothermal circulation within the Newark basin from fission-track analysis, Geology, 21, 735-738, 1993.

Tapponnier, P., and P. Molnar, Active faulting and Cenozoic tectonics of the Tien Shan, Mongolia and Baykal regions, J. Geophys. Res., 84, 34253459,1979

van der Beek, P., Flank uplift and topography at the central Baikal rift (SE Siberia): A test of kinematic models for continental extension, Tectonics, 16, 122-136, 1997

Vanneste, M., M. De Batist, A. Golmshtok, A. Kremlev, and W. Versteeg, Multi-frequency seismic study of gas hydrate-bearing sediments in Lake Baikal, Siberia, Mar. Geol., 172, 1-21, 2001.

Williams, D. F., J. Peck, E. B. Karabanov, A .A. Prokopenko, V. Kravchinsky, J. King, and M. I. Kuzmin, Lake Baikal record of continental climate response to orbital insolation during the past 5 million years, Science, 278, 1114-1117, 1997.

Windley, B. F., and M. B. Allen, Mongolian plateau: Evidence for a late Cenozoic mantle plume under central Asia, Geology, 21, 295-298, 1993.

Yin, A., Mode of Cenozoic east-west extension in Tibet suggesting a common origin of rifts in Asia during the Indo-Asian collision, J. Geophys. Res., 105, 21,745-21,759, 2000.

Zamarayev, S. M., and V. V. Ruzhich, On relationships between the Baikal rift zone and ancient structures, Tectonophysics, 45, 41-47, 1978.

Zelt, C. A., and R. B. Smith, Seismic traveltime inversion for 2-D crustal velocity structure, Geophys. J. Int., 108, 16-34, 1992

Zonenshain, L. P., and L. A. Savostin, Geodynamics of the Baikal rift zone and plate tectonics of Asia, Tectonophysics, 76, 1-45, 1981

Zonenshain, L. P., M. I. Kuzmin, and L. M. Natapov, Geology of the USSR: A Plate-Tectonic Synthesis, Geodyn. Ser, vol. 21, 242 pp., AGU, Washington, D. C., 1990.

Zorin, Y. A., and S. V. Lepina, Geothermal aspects of development of asthenospheric upwelling beneath continental rift zones, J. Geodyn., 3, $1-22,1985$.

Zorin, Y. A., V. M. Kozhevnikov, M. R. Novoselova, and E. K. Turutanov, Thickness of the lithosphere beneath the Baikal rift zone and adjacent regions, Tectonophysics, 168, 327-337, 1989.

M. H. Taylor, Department of Earth and Space Sciences, University of California, 3806 Geology Bldg., Los Angeles, CA 90095, USA. (mtaylor@ ess.ucla.edu)

U. S. ten Brink, U.S. Geological Survey, Woods Hole Field Center, Woods Hole, MA 02543, USA. (utenbrink@usgs.gov) 